\title{
IMPACT OF LEAF EATING CATERPILLAR CONTROLS ON THE DIVERSITY OF INSECTS IN ASIATIC PENNYWORT FARMS
}

\author{
NAME, J. - BUMROONGSOOK, S. \\ Department of Plant Production Technology, Faculty of Agricultural Technology, King \\ Mongkut's Institute of Technology Ladkrabang \\ 10520 Bangkok, Thailand \\ *Corresponding author \\ e-mail: suvarin.bu@kmitl.ac.th \\ (Received $7^{\text {th }}$ Aug 2017; accepted $21^{\text {st }}$ Nov 2017)
}

\begin{abstract}
Annual loss of Asiatic pennywort production is primarily due to lepidopterous larvae. The pennywort cutworm (Zonoplusia ochreata) is one of the most destructive leaf feeders of pennywort. Most Thai growers prefer chemical controls to prevent production loss. Bioinsecticide is an alternative to synthetic insecticides. Some organic growers used Bacillus thuringiensis and neem extract for lepidopterous control in pennywort farms. We should understand how diversity of target and non-targeted species in the areas is impacted by different control management. Therefore, four preventative treatments were trialed: natural control in organic farming, Bacillus thuringiensis, neem extract and abamectin, to evaluate their effect on the biodiversity of insects in Chainat, Nonthaburi and Bangkok provinces, all located in the central region of Thailand. After 8 weekly spray applications, the insects were collected using the sweep sampling method. A total of 561 insects were identified belonging to 38 different species, including 34 predator species, and 29 parasitoid species. The effect of different treatments on the species diversity index and evenness index was calculated. Shannon's species diversity index (H') was higher in the natural control area (2.74) compared to areas treated with Bt (2.09), neem extract (1.90) and abamectin pesticide (1.88). The evenness index showed a similar trend; natural control (0.82), Bt (0.57), neem extract (0.62) and abamectin (0.55). The results support the hypotheses that organic farming promote insect diversity. Environmentally insect control approaches enhance biodiversity and ecological service in farmland.
\end{abstract}

Keywords: biological control agents, bioinsecticides, natural control, Shanon diversity index, phytophagous lepidopterans, ecological balance

\section{Introduction}

The Asiatic pennywort (Centella asiatica) is a ground creeping plant belonging to the genus Centella of the Apiaceae family (De Padua and Bunyapraphatsara, 1999), and is a common medicinal herb (Yadav et al., 2012; Yasmeen et al., 2011). In the 1990s, $60 \%$ of Thailand's exports were agricultural products. Twelve kinds of vegetables were exported to the European market including Asiatic pennywort which was found to contain excessive chemical residues, due to inappropriate and excessive use of pesticides for controlling insects (Devarrewaerre, 1995; FAO, 1998). The main issue of pennywort production for local consumption and for export is insect infestation resulting in decreased productivity (Pathak and Khan, 1994). There are many studies which suggest chemical usage for pest control can risk pest resurgence and decreased diversity (Montanez and Amarillo, 2014). Organic farming systems rely on ecological services and natural balance to provide agricultural sustainability. Organic agriculture is mainly defined as the ban of chemical pesticides, chemical fertilizers, growth hormones, antibiotics, and genetically modified organisms. Furthermore, habitat management is recommended to increase biodiversity and especially the abundance and diversity of 
natural enemies (Zehnder et al., 2007). Modern farming practices (mechanization, mono-cropping, hybrid varieties and genetically modified (GM) crops) combined with the heavy use of agri-chemicals (fertilizers, pesticides and herbicides) have resulted in a loss of biodiversity in agricultural landscapes and surrounding areas. Agriculture that is rich in biodiversity, possess greater resilience and are, therefore, able to recover more readily from biotic and abiotic stresses such as drought, environmental degradation, pests, diseases, and epidemics. Furthermore, biodiversity conservation in agricultural landscapes promotes higher species richness and facilitates metapopulation processes between habitats (Wittebolle et al., 2009; Crowder et al., 2010).

Many different types of caterpillars, especially Zonoplusia ochreata, devour the leaves of pennywort and can strip the leaves in days during peak seasons. Organic insecticides are available for caterpillar control including Bacillus thuringiensis $(\mathrm{Bt})$ and neem oil. Jun-Ce et al. (2015) compared arthropod populations in spray Bt and organic cotton crops and found no significant differences in the population of arthropod taxa collected namely, stink bugs, plant bugs, Geocoris spp., Orius spp., Solenopsis invicta, ladybeetles, and spiders. However, some previous studies suggest that transgenic Bt cotton has detrimental impact on biodiversity (Cattaneo et al., 2006; Sisterson et al., 2004), especially when compared with conventional chemical sprays for insect control (Marvier et al., 2007). Lawo et al. (2009) reported that transgenic Bt cotton will alter the arthropod community directly by reducing the abundance of Helicoverpa spp. and some other lepidopteran species. Bt cotton may also have indirect, effects on the abundance of predators and parasitoids that specialize on larvae of Helicoverpa spp. or other lepidopteran species controlled by Bt. Neem products can use for lepidopterous larva control (Ukeh et al., 2007). Its bioactivity includes antifeedant, insecticidal activity and disruption to growth and development of insects (Senthil-Nathan, 2013). Both Bt and neem extract has long been recognized as environmental friendly biopesticides. Many synthetic insecticides are available on the market but growers generally prefer abamectin mostly for insect control in Asiatic pennywort growing areas (Ngernyu and Bumroongsook, 2012). However, organic Asiatic pennywort farming rely on biological control agents which are currently implemented to resolve the chemical contamination problems of export vegetables.

Therefore, we need to assess the impact of various methods for controlling leaf eating caterpillars of Asiatic pennywort using different insecticides as compared to natural control in organic farming on insect diversity. The diversity and evenness index approaches is used to evaluate whether these treatments are suitable as eco-friendly products for organic farming.

\section{Materials and methods}

\section{Study area}

The studies were conducted from April to July 2016 in Chainat, Nonthaburi and Bangkok provinces, all located in the central region of Thailand (Fig. 1). These three provinces received 82.5-456.5 $\mathrm{mm}$ of rainfall in 2015-2016. During the sampling period, mean temperatures ranged from $30.2^{\circ} \mathrm{C}$ to $34.9^{\circ} \mathrm{C}$ while, the average relative humidity varied from 54.6-75.5\%.

Chainat: located at Sankhaburi, a district in the south of Chainat province (Lat. $15^{\circ}$ $11^{\prime} \mathrm{N}$ : Long. $100^{\circ} 7^{\prime} \mathrm{E}$ ), surrounded by rice fields. The study area was three hectares. 
Nonthaburi: located at Sai Noi, in the north west of Nonthaburi province (Lat. $13^{\circ}$ $47^{\prime} \mathrm{N}$ : $100^{\circ} 15^{\prime}$ E) with small irrigation canals situated in an Asiatic pennywort plantation; one side bordered by the local road and the other side by a rice field.

Bangkok: located at Ladkrabang, to the east of Bangkok (Lat. $13^{\circ} 43^{\prime} \mathrm{N}$ : Long. $100^{\circ}$ $47^{\prime}$ E), both sides connected to small irrigation canals and surrounded by a vegetable crop plantation.

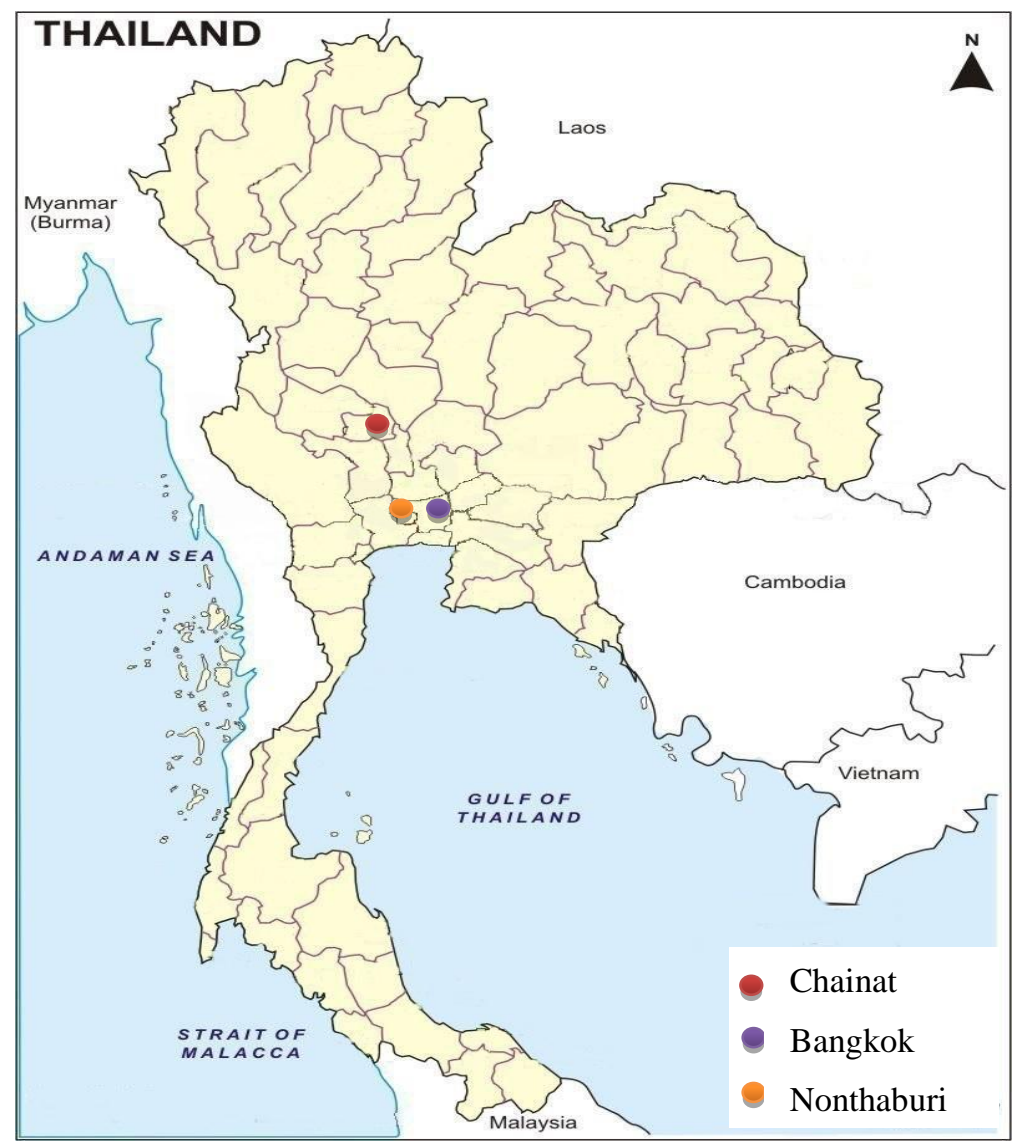

Figure 1. The map showing the three study location of Asiatic pennywort farms

\section{Treatment application}

One-month old Asiatic pennywort with almost uniform growth were selected for treatment. The experiment comprised Asiatic pennywort farmed using natural control in organic farming methods (T1); neem extract at $300 \mathrm{ml}$ per $20 \mathrm{~L}$ water (T2); Bacillus thuringiensis var. aizawai at $80 \mathrm{ml}$ per $20 \mathrm{~L}$ water (T3); and abamectin $1.8 \% \mathrm{w} / \mathrm{v} 80 \mathrm{ml}$ per $20 \mathrm{~L}$ water (T4). The insecticides were sprayed weekly onto the leaves of Asiatic pennywort for 8 weeks.

\section{Insect Sampling of Asiatic pennywort farms}

At each site, insect sampling was conducted between 9-11 am in April to July 2016. The insects were collected using the sweep sampling method described by Gadagakar et al. (1990). Nets made of thick cotton cloth were used with a diameter of $30 \mathrm{~cm}$ at the mouth and a bag length of $60 \mathrm{~cm}$. The sampling method was to sweep on and around 
the plants 100 times/site. The collected insects were transferred into vials in $70 \%$ alcohol for identification. Insects were identified based on morphological characteristics and classified according to family, order and species (Heisswolf et al., 2010).

\section{Data analysis}

Study area diversity was calculated based on species diversity using the Shannon diversity index (Shannon, 1948; Eq. 1):

$$
H=-\sum_{i=1}^{s}\left(P_{i} \ln P_{i}\right)
$$

where $\mathrm{H}$ is the Shannon diversity index, $\mathrm{P}_{\mathrm{i}}$ is the proportion of individuals found in species $\mathrm{i}, \mathrm{s}$ is the total number of species.

We also adopt a Simpson index of diversity which is widely used for measurement of biodiversity (Simpson, 1949; Eq. 2):

$$
1-D=1-\frac{\sum n(n-1)}{N(N-1)}
$$

where 1-D is the Simpson index of diversity, $\mathrm{n}=$ the total number of organisms of a particular species, $\mathrm{N}=$ the total number of organisms of all species.

The evenness index was calculated using Pielou's formula (Pielou, 1966; Eq. 3):

$$
E=H^{\prime} / \ln S
$$

where $\mathrm{E}$ is the evenness index, $\mathrm{H}$ is the Shannon diversity index, $\mathrm{S}$ is the total number of species.

\section{Results}

Differences among predators, parasitoids and insect pest communities in the Asiatic pennywort farms

A total of 561 insects belonging to 38 different species, including 34 predator species, 29 parasitoid species and 498 insect pest species were collected using the sweep sampling method. The effect of different treatments on the species diversity index and evenness index was higher in the natural control compared to Bt $(2.09,0.62)$, neem extract $(1.90,0.57)$ and abamectin pesticide $(1.88,0.55)$ (Table 1, Fig. 2). The Shannon's species diversity index (H') showed a negative effect of abamectin treatment compared with the natural control of organic farming in three Asiatic pennywort plantations. There was no discernible effect of Bt and neem treatment on Shannon's species diversity index (H'). Shannon's species evenness index (E) was higher in organic farming compared to the abamectin treatment. The $\mathrm{Bt}$ and neem extract had little impact on the diversity of predator, parasitoid and insect pests. The results for predator, parasitoid and insect pest species diversity and evenness were similar for all insect species, which confirms that insecticide treatment has a considerable negative effect on Shannon's species diversity and evenness. 
The results showed a significant effect on mean abundance and species richness, with higher values in organic farming, but no effect on diversity $\left(H^{\prime}\right)$ or evenness $(E ')$. The mean abundance of the predator, parasitoid and insect pests per sweeping net was significantly lower in the abamectin treatment compared to the organic farming, Bt and neem treatments (Table 1).

Table 1. Diversity of predator, parasitoid and insect pest for the natural control, Bt, neem and abamectin treatments of Asiatic pennywort farms

\begin{tabular}{c|c|c|c|c|c}
\hline Treatment & Species & $\begin{array}{c}\text { Simpson index of } \\
\text { diversity (1-D) }\end{array}$ & $\begin{array}{c}\text { Shannon diversity } \\
\text { index }(\mathbf{H})\end{array}$ & $\begin{array}{c}\text { Evenness } \\
(\mathbf{E})\end{array}$ & $\begin{array}{c}\text { Total of } \\
\text { insect }\end{array}$ \\
\hline Natural control & 38 & 0.10 & 2.74 & 0.82 & 250 \\
Neem & 38 & 0.07 & 1.90 & 0.57 & 124 \\
Bt & 38 & 0.08 & 2.09 & 0.62 & 135 \\
Abamectin & 38 & 0.05 & 1.88 & 0.55 & 52 \\
\hline
\end{tabular}

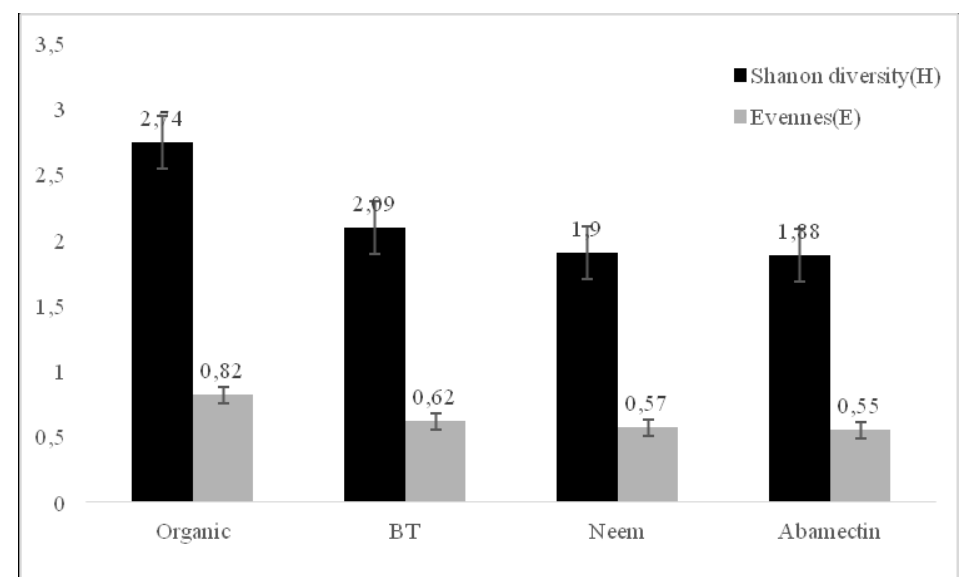

Figure 2. Shanon diversity index $(H)$ and evenness $(E)$ for the natural control in organic farming, Bt, neem extract and abamectin of Asiatic pennywort farms

\section{Composition of pest insect communities}

The main predators found in organic farming, Bt, neem extract and abamectin on Asiatic pennywort are shown in Table 2. A total of 498 pest insects were counted in Asiatic pennywort (218 in organic farming, 118 in Bt, 111 in neem extract and 51 in abamectin). Different insect pests were recorded on the organic, neem, Bt and abamectin treatment. The dominant groups of insect found in the Asiatic pennywort were Cicadellidae, Agromyzidae, Thripidae and Noctuidae. In the organic farms, a significantly higher abundance of insect was observed in comparison to the $\mathrm{Bt}$, neem, and abamectin treatment namely, Agromyzidae $(p<0.001)$, Chrysomelidae $(p<0.001)$, Thripidae ( $p<0.001)$, Cicadellidae $(p<0.001)$, Noctuidae $(p<0.001)$, Arctiidae $(p<$ $0.001)$ and Agromyzidae ( $p<0.001$ ). The following were significantly more abundant in Bt and neem than in organic namely, Delphacidae $(p \leq 0.001)$, Acrididae $(p \leq 0.001)$, Aphididae $(p \leq 0.001)$, Chrysomelidae $(p \leq 0.001)$, Tetrigidae $(p \leq 0.001)$, Cecidomyiidae $(p \leq 0.001)$ and Tridactylidae $(p \leq 0.001)$. Generally, the phytophagous Lepidopteran of pennywort in organic farms were Zonoplusia ochreata, Diasemia accalis, and Spodoptera exigua (Fig. 3). 
Table 2. Mean presence per sampling point of insect pest on Asiatic pennywort in April to July 2016. Each value was the mean of three fields; SE was calculated using each sampling data in each farm as an independent data. Statistical significance based on ANOVA

\begin{tabular}{c|c|c|c|c|c}
\hline Pest taxa & $\begin{array}{c}\text { Organic [Mean/3 } \\
\text { sites (S.E.)] }\end{array}$ & $\begin{array}{c}\text { Bt [Mean/3 } \\
\text { sites (S.E.)] }\end{array}$ & $\begin{array}{c}\text { Neem [Mean/3 } \\
\text { sites (S.E.)] }\end{array}$ & $\begin{array}{c}\text { Abamectin [Mean/3 } \\
\text { sites (S.E.)] }\end{array}$ & $\boldsymbol{P}$ \\
\hline Delphacidae & $2.00(0.01)$ & $3.00(0.61)$ & $1.00(0.01)$ & $1.67(0.08)$ & 0.001 \\
Agromyzidae & $24.33(0.57)$ & $6.00(0.81)$ & $14.33(0.77)$ & $1.67(0.08)$ & 0.001 \\
Chrysomelidae & $2.33(0.53)$ & $0.33(0.08)$ & $4.00(0.58)$ & $0.33(0.08)$ & 0.001 \\
Tetrigidae & $2.67(0.15)$ & $3.33(0.21)$ & $6.33(0.51)$ & $2.67(0.31)$ & 0.001 \\
Acrididae & $1.33(0.53)$ & $2.00(0.05)$ & $0.33(0.08)$ & $1.33(0.31)$ & 0.001 \\
Thripidae & $5.67(0.04)$ & $2.00(0.01)$ & $4.00(0.20)$ & $2.00(0.46)$ & 0.001 \\
Cicadellidae & $27.00(0.29)$ & $14.00(0.94)$ & $4.67(0.51)$ & $3.33(0.31)$ & 0.001 \\
Aphididae & $0.67(0.08)$ & $1.00(0.01)$ & $0.00(0.00)$ & $0.33(0.08)$ & 0.001 \\
Cecidomyiidae & $1.33(0.58)$ & $3.00(0.61)$ & $7.67(0.42)$ & $0.67(0.08)$ & 0.001 \\
Tridactylidae & $1.33(0.53)$ & $0.33(0.08)$ & $3.33(0.06)$ & $0.33(0.08)$ & 0.001 \\
Noctuidae & $3.33(0.15)$ & $0.67(0.07)$ & $1.33(0.53)$ & $0.00(0.00)$ & 0.001 \\
Arctiidae & $2.00(0.00)$ & $1.00(0.03)$ & $0.00(0.00)$ & $2.00(0.65)$ & 0.001 \\
Agromyzidae & $1.33(0.53)$ & $0.33(0.08)$ & $1.00(0.73)$ & $0.67(0.15)$ & 0.001 \\
\hline Total & $75.33(3.99)$ & $37.01(3.56)$ & $48.00(3.61)$ & $17.00(2.67)$ & 0.013 \\
\hline
\end{tabular}

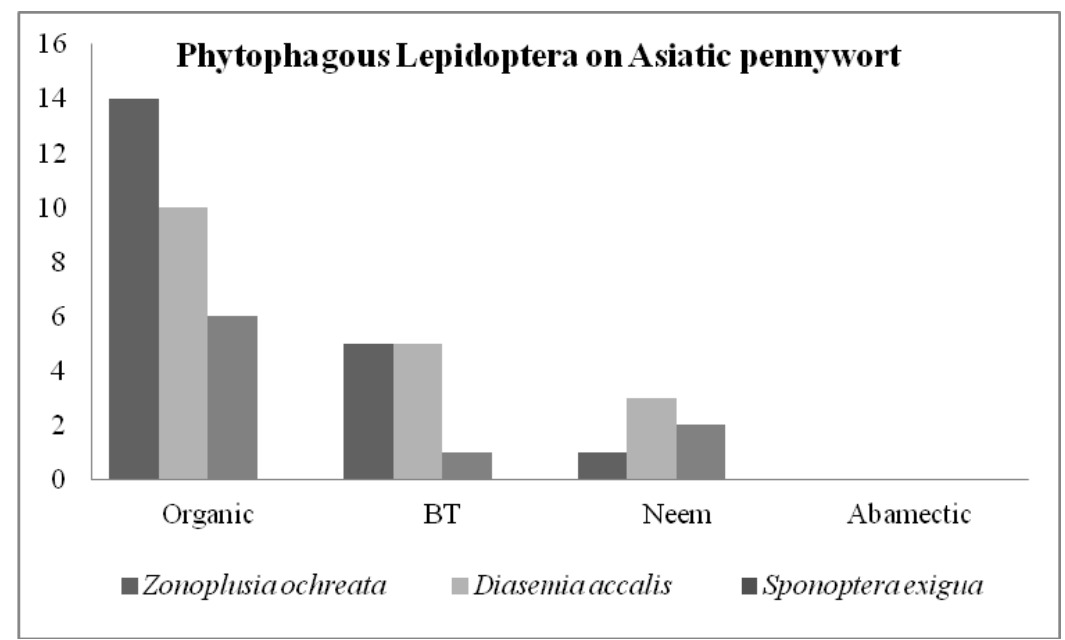

Figure 3. Different composition of lepidopteran pest fauna on Asiatic pennywort farms. The data were obtained from three field pairs

\section{Composition of predator communities}

Table 3 lists the main predators in Asiatic pennywort farms. In detail, a total of 34 predator specimens (18 in organic farming, 8 in Bt, 7 in neem and 1 in abamectin treatment) were recorded on Asiatic pennywort. At the farms treated with abamectin compared to the organic farming, $\mathrm{Bt}$, and neem extract, a minimal abundance of total predators was detected. Chrysomelidae $(p<0.005)$, and Coccinellidae $(p<0.001)$ were significantly more abundant in organic farming than in Bt, neem extract and abamectin treatment. None of these predators were found to attack the larvae of Lepidopteran pests in the field. 
Table 3. Mean presence per sampling point of predator on Asiatic pennywort in April to July 2016. Each value is the mean of three fields; SE was calculated using each sampling data in each farm as an independent data. Statistical significance based on ANOVA

\begin{tabular}{|c|c|c|c|c|c|}
\hline Predator taxa & $\begin{array}{c}\text { Organic [Mean/3 } \\
\text { sites (S.E.)] }\end{array}$ & \begin{tabular}{|c|} 
Bt $[$ Mean/3 sites \\
(S.E.) $]$ \\
\end{tabular} & $\begin{array}{c}\text { Neem [Mean/3 } \\
\text { sites (S.E.)] }\end{array}$ & $\begin{array}{c}\text { Abamectin [Mean/3 } \\
\text { sites (S.E.)] }\end{array}$ & $P$ \\
\hline Chrysomelidae & $3.66(0.13)$ & $1.00(0.03)$ & $2.00(0.02)$ & $0.33(0.08)$ & 0.005 \\
\hline Agrionidae & $1.33(0.08)$ & $0.67(0.28)$ & $0.33(0.08)$ & $0.33(0.08)$ & 0.115 \\
\hline Coccinellidae & $0.33(0.10)$ & $0.00(0.00)$ & $0.00(0.00)$ & $0.00(0.00)$ & 0.001 \\
\hline Pentatomidae & $0.66(0.18)$ & $0.67(0.15)$ & $0.33(0.08)$ & $0.00(0.00)$ & 0.172 \\
\hline Staphylinidae & $0.33(0.18)$ & $0.00(0.00)$ & $0.00(0.00)$ & $0.00(0.00)$ & 0.203 \\
\hline Total & $6.31(0.67)$ & $2.34(0.46)$ & $2.66(0.18)$ & $0.66(0.16)$ & 0.496 \\
\hline
\end{tabular}

\section{Composition of parasitoid communities}

There were 14 parasitoids collected in Asiatic pennywort treated with organic farming, 10 collected from Bt treated areas, 5 collected from neem extract treated areas and none found in the abamectin treated areas (Table 4). The number of parasitoids were significantly higher in organic farms compared to Bt, neem extract and abamectin namely, Cotesia flavipes $(p<0.001)$ and Chelonus sp. $(p<0.007)$. Yet, the two parasitoids Euplectrus sp. nr. bicolor $(p<0.001)$ and Cotesia sp. $(p<0.003)$ were significantly more abundant in $\mathrm{Bt}$ and neem extract than in organic farms. Euplectrus $s p$. nr. bicolor is a larval ectoparasitoid of pennywort cutworm, Zonoplusia ochreata.

Table 4. Mean presence per sampling point of parasitoids on Asiatic pennywort in April to July 2016. Each value was the mean of three fields; SE was calculated using each sampling data in each farm as an independent data. Statistical significance based on ANOVA

\begin{tabular}{c|c|c|c|c|c}
\hline Parasitoid & $\begin{array}{c}\text { Organic [Mean/3 } \\
\text { sites (S.E.)] }\end{array}$ & $\begin{array}{c}\text { Bt [Mean/3 } \\
\text { sites (S.E.)] }\end{array}$ & $\begin{array}{c}\text { Neem [Mean/3 } \\
\text { sites (S.E.) }\end{array}$ & $\begin{array}{c}\text { Abamectin [Mean/3 } \\
\text { sites (S.E.)] }\end{array}$ & $\boldsymbol{P}$ \\
\hline $\begin{array}{c}\text { Euplectrus } \text { sp. nr. } \\
\text { bicolor }\end{array}$ & $1.00(0.00)$ & $2.33(0.58)$ & $0.33(0.08)$ & $0.00(0.00)$ & 0.001 \\
Cotesia flavipes & $2.00(0.03)$ & $1.00(0.03)$ & $0.00(0.00)$ & $0.00(0.00)$ & 0.001 \\
Chelonus sp. & $1.00(0.02)$ & $0.00(0.00)$ & $0.00(0.00)$ & $0.00(0.00)$ & 0.007 \\
Cotesia sp. & $0.67(0.08)$ & $0.00(0.00)$ & $1.33(0.03)$ & $0.00(0.00)$ & 0.003 \\
\hline Total & $4.67(0.13)$ & $3.33(0.61)$ & $1.67(0.11)$ & $0.00(0.00)$ & 0.012 \\
\hline
\end{tabular}

\section{Discussion}

The loss of biodiversity is related with more extensive agricultural areas (Froidevaux et al., 2017). Organic farming is used to alleviate the problems associated with biodiversity conservation in intensive agricultural practices. Our study showed a greater level of insect diversity (predator, parasitoid, and insect pest) in organic farms compared with conventional methods (Bt, neem extract, and abamectin) of Asiatic pennywort plantations. Organic crops increase the taxonomic richness and abundance of insects, therefore it conserves biodiversity (Montanez and Amarillo-Suárez, 2014). Tuck et al. (2014) state that organic farming promotes species richness and conserves biodiversity. 
Both Bt and neem extract treatment affect diversity indices. Lu et al. (2014) showed that there was no the consistent difference in abundance, diversity and species richness of beneficial arthropods in Bt spray and conventional cotton communities. Our studies showed neem extract has better insect control than Bt. Neem extract has insecticidal activity to a wide range of insects (George et al., 2014). Resende et al. (2016) indicated that the richness and diversity of insects depend on location and insecticide spray. Various control practices used in modern agriculture are related to the decline of biodiversity in production areas. To restore biodiversity is to implement crop production using biodiversity-based ecosystem services (Geiger, 2010)

\section{Conclusions}

This research is addressing various scales of lepidopterous management based on diversity measures. Diversity indices provide useful information for ecological structure, but they do not include species interaction. The sweep sampling could not detect all the insects in the areas and effect on the diversity index estimation. This is the first report on a survey of insect pests and natural enemies found in pennywort farming in Thailand. In the study it is proven that organic farming of Asiatic pennywort helps to conserve predators and parasites and enhances the ecology balance and insect diversity. A broad spectrum insecticide like abamectin had the greatest impact on biodiversity and abundance of insects. Bt and neem oil are more selective organic insecticides and had effect on predator and parasite diversity. However, critical questions remain including importance of parasitoid species and their relative abundance as a biological control agent. The impact of parasitoids on lepidopterous larvae should be investigated to develop alternatives for better control tactics in organic farming practice.

Acknowledgements. This research was supported by 2015 KMITL annual research grant. Thanks go to Assoc. Prof. Sean Tigwattanont for insect identification assistance.

\section{REFERENCES}

[1] Cattaneo, M. G., Yafuso, C., Schmidt, C., Huang, C. Y., Rahman, M., Olson, C., EllersKirk, C., Orr, B. J., Marsh, S. E., Antilla, L., Dutilleul, P., Carrière, Y. (2006): Farm-scale evaluation of the impact of transgenic cotton on biodiversity, pesticide use and yield. Proceedings of the National Academy of Sciences of the United States 103: 7571-7576.

[2] Crowder, D. W., Northfield, T. D., Strand, M. R., Snyder, W. E. (2010): Organic agriculture promotes evenness and natural pest control. - Nature Letters 466: 109-112.

[3] De Padua, L. S., Bunyapraphatsara, N. (1999): Medicinal and Poisonous Plants 1. - In: Oyen, L. P. A., Dung, N. X. (eds.) Plant Resources of South-East Asia. Backhuys, Leiden.

[4] Devarrewaerre, M. P. (1995): National Strategies for Vegetable Production and Hybrid Seed Technology in Sub-tropical and Tropical Asia, p. 1-14. - Asia Pacific Seed Association, Bangkok.

[5] FAO. (1998): Selected indicators of food and agriculture in the Asia-Pacific region 198797. - FAO, Bangkok.

[6] Froidevaux, J. S. P., Louboutin, B., Jones, G. (2017). Does organic farming enhance biodiversity in Mediterranean vineyards? A case study with bats and arachnids. Agriculture, Ecosystems \& Environment 249: 112-122. 
[7] Gadagakar, R., Chandrasekhar, K., Nair, P. (1990): Insect species diversity in the tropics: sampling method and case study. - Journal of the Bombay Natural History Society 87(3): 328-353.

[8] Geiger, F., Bengtssonb, J., Berendse, F., Weisser, W. W., Emmerson, M., Morales, M. B., Ceryngier, P., Liira, J., Tscharntke, T., Winqvist, C., Eggers, S., Bommarco, R., Part, T., Bretagnolle, V., Plantegenest, M., Clement, L. W., Dennis, C., Palmer, C., Onate, J. J., Guerrero, I., Hawro, V., Aavik, T., Thies, C., Flohre, A., Hanke, S., Fischer, C., Goedhart, P. W., Inchausti, P. (2010): Persistent negative effects of pesticides on biodiversity and biological control potential on European farmland. - Basic and Applied Ecology 11: 97-105.

[9] George, D. R., Finn, R. D., Graham, K. M., Sparagano, O. A. (2014): Present and future potential of plant-derived products to control arthropods of veterinary and medical significance. - Parasit Vectors 15: 7-28.

[10] Heisswolf, A., Käär, M., Klemola, T. Ruohomäki, K. (2010): Local outbreaks of Operophtera brumata and Operophtera fagata cannot be explained by low vulnerability to pupal predation. - Agricultural and Forest Entomology 12: 81-87.

[11] Jun-Ce, T., Ju, Y., Li-Ping, L., Jorg, R., Anthony, M. S. (2015): Bt crops benefit natural enemies to control non-target pests. - Scientific Reports 5: 16636.

[12] Lawo, N. C., Wäckers, F. L., Romeis, J. (2009): Indian Bt cotton varieties do not affect the performance of cotton aphids. - PLoS ONE 4: 4804.

[13] Lu, Z. B., Tian, J. C., Han, N. S., Hu, C., Peng, Y. F., David, S., Ye, G. Y. (2014): No direct effects of two transgenic Bt rice lines, T1C-19 and T2A-1, on the arthropod communities. - Environmental Entomology 43(5): 1453-1463.

[14] Marvier, M., McCreedy, C., Regetz, J., Kareiva, P. (2007): A meta-analysis of effects of Bt cotton and maize on nontarget invertebrates. - Science 316: 1475-1477.

[15] Montanez, M. N., Amarillo-Suárez, A. (2014): Impact of organic crops on the diversity of insects: A review of recent research. - Revista Colombiana de Entomologia 40(2): 131-142.

[16] Naranjo, S. E., (2009): Impacts of Bt crops on non-target invertebrates and insecticide use patterns. - CAB Reviews Perspectives in Agriculture Veterinary Science Nutrition and Natural Resources 4: 1-23.

[17] Ngernyu, P., Bumroongsook, S. (2012): Biology of cutworm, Zonoplusia ochreata. - The 10 National Horticultural Congress, pp. 177-183. Miracle Grand Convention Hotel, Bangkok.

[18] Pathak, M. D., Khan, Z. R. (1994): Insect Pests of Rice. - International Rice Research Institute, Manila.

[19] Pielou, E. C. (1966): The measurement of diversity in different types of biological collections. - Journal of Theoretical Biology 13: 131-144.

[20] Resende, D. C., Mendes, S. M., Murucci, R. C., Silva, A. D. C., Campanha, M. M., Waquil, J. M. (2016): Does Bt maize cultivation affect the non-target insect community in the agro ecosystem? - Revista Brasileira de Entomologia 60(1): 82-93.

[21] Senthil-Nathan, S. (2013): Physiological and biochemical effect of neem and other Meliaceae plants secondary metabolites against Lepidopteran insects. - Front Hysiology 4: 1-17. doi: 10.3389/fphys.2013.00359.

[22] Shannon, C. E. (1948): A mathematical theory of communication. - The Bell System Technical Journal 27: 379-423.

[23] Simpson, E. H. (1949): Measurement of diversity. - Nature 163: 688.

[24] Tuck, S. L., Winqvist, C., Mota, F., Ahnström, J., Turnbull, L. A., Bengtsson, J. (2014): Land-use intensity and the effects of organic farming on biodiversity: a hierarchical metaanalysis. - Journal of Applied Ecology 51(3): 746-755.

[25] Ukeh, D. A., Emossairue, S. O., Udo, I. A., Ofem, U. A. (2007): Field evaluation of neem (Azadirachta indica A. Juss) product for the management pf lepidopterous stem borers of Maize (Zea mays L.) in Calabar, Nigeria. - Research Journal of Applied Science 2: 653658. 
[26] Whitehouse, M. E. A., Wilson, L. J., Fitt, G. P. (2005): A comparison of arthropod communities in transgenic Bt and conventional cotton in Australia. - Environmental Entomology 34: 1224-1241.

[27] Wittebolle, L., Marzorati, M., Clement, L., Balloi, A. Daffonchio, D., Heylen, K., De Vos, P. Verstraete, W., Boon, N. (2009): Initial community evenness favours functionality under selective stress. - Nature 458: 623-626.

[28] Yadav, K., Singh, N., Verma, S. (2012): Plant tissue culture: a biotechnological tool for solving the problem of propagation of multipurpose endangered medicinal plants in India. - Journal of Agricultural Technology 8: 305-318.

[29] Yasmeen, S., Tajul, M. I., Yuvarani, N., Sariah, M. (2011): The conjunctive use of compost tea and inorganic fertiliser on the growth, yieldand terpenoid content of Centella asiatica (L.) urban. - Scientia Horticulturae 130: 289-295.

[30] Zehnder, G., Gurr, G. M., Kuhne, S., Wade, M. R., Wratten, S. D., Wyss, E. (2007): Arthropod pest management in organic crops. - Annual Review of Entomology 52: 57-80. 